\title{
Contribution of Digitalization to the Brand Registry Applications in the Context of Globalization
}

\author{
Gümüş S. ${ }^{1}$ \\ ${ }^{1}$ Sema GÜMÜŞ, İstanbul Aydın University, (Turkey) \\ e-mail: gumussema@gmail.com
}

\begin{abstract}
Public authorities, which are part of the state, are opening up institutions for citizens. Nowadays, when the transition to the digital age, which is a part of globalization, is taking place, the Internet has to be a dynamic structure that can adapt to the changing conditions. Considering these, public institutions of the states can deliver their services to citizens in innovative ways. Thus, the public authorities now utilize technological services in public offering of public services and electronicize these services. In this way, it is aimed to provide the highest quality service to the citizens with the least cost and labor. These technological breakthroughs in the process of globalization accelerate and facilitate information sharing by integrating the convenience of technology with e-transformation and e-government concepts. This study is related to the regulation on access through e-government, which is widespread in our country, and to apply to online applications made by Turkish Patent and Trademark Authority. In particular, opinions and observations on trademark registration applications and post-registration services were made and opinions were taken on the sustainability/ accessibility of transactions from the corporate experts.
\end{abstract}

Keywords: Globalization, Digitization, Trademark, Trademark Registered, e-Government.

\section{Introduction}

Recently, one of the most talked about subjects is globalization, and technology, especially digital technologies. The globalization of all over the world with the boundaries of everything to achieve instant access to digitalization takes place. For this reason, globalization and technology have affected all our habits. This has also changed the traditional ways of public service delivery, and states have become aware of the need to modernize their service delivery in order to strengthen and maintain their positions in global competition. Digitalization with globalization has significantly affected the public sector. In this transformation in the concept of public service delivery, electronic state (egovernment) applications emerged with the use of information and communication technologies. With this application, the procedures resulting from the excess of bureaucratic procedures have been reduced and significant time and financial gain has been achieved.

The other part of the study is the important element of the marketing activities that provide the communication between the consumer and the product that distinguishes the goods and / or services from the other enterprises that promote the goods and / or services. In the legal context, a brand is any sign that can distinguish the goods or services of a business from other businesses. The brand is an immaterial right and the acquisition of this right is only through the registration of the trademark. The trademark is registered with the Turkish Patent and Trademark Authority.

In this study, the integration of public services into digital environment and the contribution of globalization and digitalization to trademark registration applications were examined. In this context, physical brand registration application and post-registration processes, online trademark registration and post-registration procedures, weaknesses and strengths of online transactions, online and physical brand registration application numbers per year and the issues related to the comparison of these numbers are examined. 


\section{Literature}

The phenomenon of globalization is one of the issues that are written and discussed today. The word "globalization" derived from the English word "globe" meaning the world it means all spheres or worlds, global or worldly. As McLuhan (1962), a local distant settlement, which is the main member of a global village, is formed by the events of miles of local, local formations, or vice versa, in order to intensify the unity of the world-wide associations that connect them in this way. (Giddens, 2004: 69). Thanks to globalization, mutual interaction has increased and this interaction has led to the formation of new formations.

With globalization, there are dramatic changes in almost every field and the necessity to live in a complex environment. (Akın, 2001: 77). Bauman stated that globalization affects societies in economic, political, cultural and technological contexts. In short, globalization as we call it today; It has gained importance as a result of modernization (Bauman, 2017: 8). In globalization, it is a necessity for the societies to take into account the competition in the global arena in order to keep up with the developments.

Globalization makes itself felt through the transmission of digitalized objects through a series of networks. The most effective of these networks is information and communication technologies and the accompanying internet. Globalization is gaining a historical momentum especially with the spread of technology of information and communication, and the technologies leading to this spread may be irreversible in our lives. Globalization, a process involving development and change, has developed economic, social and political relations between countries through information and communication technologies. Globalization may also include interrelated issues such as better recognition of the beliefs and expectations of different societies and cultures, and the intensification of international relations. As a result of the developments at the global level, the concept of "digital society son made itself felt instead of"transformation into an information society Küresel.

In digitalization, which triggers digital society, data transferred from computer to computer are digitally expressed. Digital is a process of getting to work. In this context digitality; Analog data is encoded and transferred to computer-based systems. Digitality feature brings easy and fast access to data (Yengin, 2012: 126). However, with the spread of computers and the Internet over time, beyond the digitalization of the data, the processes have also been digitized. Thanks to these developments, the digital revolution has changed the world we live in with the use of fiber optic cables everywhere. The digital term which comes into our lives with the concept of digitalization, the meaning of the dictionary is to show numerical data on the screen. According to Gartner, digitization (digitizing) is the process of transition from analog to digital form.

Digital technologies are technologies that lead to innovations in all transmission and recording processes, replacing analogue technologies. Digitalization, which offers important possibilities in terms of transmission and recording processes, ensures that once digitalized data can be transmitted, stored and stored easily (Hepkon, 2011: 15). Thus, digitalization is becoming more and more important in our daily lives. It seems to have changed everything quite quickly and has become everywhere for everyone. It is also considered that all these changes and all aspects of life are based on modernization.

Digitalization is the use of digital technologies to change a business model and provide new revenue and value generation opportunities. Digitalization is the use of digital technologies and the information used to transform business operations (Yankın, 2019: 9). Digitalization has become an important force that regulates and changes human relations, consumer behavior, and marketing channels of businesses in the current time period and social life. With the digitalization, existing products or services have been restructured with information technologies. Thus, services and products with features that can be programmed, addressable, sensitive, communication-based, intelligent, traceable and able to connect with other devices and systems have become a closer part of life.

Today, with the widespread use of the Internet, public institutions tend to approach the concept of governance in the digital age. The public sector, which is considered to be heavy-handed bulky bureaucratic structures, is transformed into effective structures by the use of information technologies (Sönmez, 2016: 153). The use of information and communication technologies in public administration is often associated with reform programs aimed at reducing inefficiency caused by unnecessary bureaucratic procedures. 
Digitalization has significantly affected the public sector. Information and communication technologies are thought to have a central role in this transformation of public service provision. In this respect, public institutions' approach to providing services to citizens is approaching private sector enterprises. In this context, public institutions tend to be transformed into digital institutions with partial or complete digitalization of their administrative processes and their interaction with citizens (Buffat, 2015: 150). In this sense, information technology in public administration is used in the public sector in line with the point of view that approaches to the private sector should be applied in the public sector in order to reduce the bureaucracy (Cordella and Tempini, 2015: 279). Information and communication technologies are thought to have a central role in this transformation of public service provision.

In the public sector, electronic state (e-government) applications have emerged with the use of information and communication technologies. With this application, the procedures resulting from the excess of bureaucratic procedures have been reduced and significant time and financial gain has been achieved. With the use of digital technologies, analog recordings were first processed in a digital environment (automation) and processes were digitized (e-service). This digital transformation process affected all institutions as well as public institutions. New ways of public service delivery are now being sought and e-government applications have emerged as a result of these searches.

Internet (online/online) which is at the center of information and communication technologies and which manipulates globalization, the technological revolution which has started in the last thirty years, has led to a rapid and large transformation in the functions of the state as it is possible to provide services over the internet. Although these developments are important, concrete steps have been taken in the 2000s to present public services in electronic environment. Online transactions refer to the stage in which public institutions connect to each other over a general network, create a structure that allows integrated, uninterrupted and uninterrupted service delivery, and that citizens can easily access all services through a single address (Çarıkcı, 2010: 103). The advantages of online transactions, in terms of public institutions, are easily ensured through access.

The e-Europe Action Plan, e-Turkey initiative was launched in 2001 , to be adapted to Turkey. In 2003 by Prime Minister Circular until then different organizations and carried out by the organizations the knowledge and the State Planning Organization of the work on communications technology (DPT) liability in the e-transformation Turkey project, it was decided to combine under the name (Ulaştırma, Denizcilik ve Haberleşme Bakanlığı, 2017: 2, 2017: 2). In addition, sharing of information and documents between public institutions can also be made through e-government. In line with all the preparation and work performed, www.turkiye.gov.t the portal has moved to the digital platform of public services was implemented in 2008 and has continued until today expands its presence. In addition to this portal, there are different sites that different public institutions have created to provide services.

Online transactions, thanks to the advantages and opportunities provided for both undertakings and public institutions, are now becoming widespread in our lives. The e-government, which is an important potential for many different sectors, constitutes the perception of trust among citizens. The concept of e-government, ie electronic state, is defined as the use of information technologies in the internal functioning of the state and the services it provides. The use of the concept in English (e-government) is used as electronic government and management (Özcivelek, 2003: 1). The concept of the electronic state (e-government) was first mentioned in the US in 1993 in a report on national performance evaluation. According to the definition of Aydın (2013: 505); egovernment; the duties and services that the state is obliged to fulfill against the citizens and the duties and services of the citizens against the state in mutual electronic communication and transaction environments. In general, e-government means that public services can be made electronically through networks that can be accessed by open or limited users without the need for direct connection or physical exchange.

With the globalization, traditional forms of public service delivery have changed and governments have become aware of the need to modernize their service delivery in order to strengthen and maintain their positions in global competition. In the 1980s, e-transformation started to happen. As a continuation of this process, the policies in the field of science and technology started to be reshaped between the years 1990-2000 and significant progress was made in realizing the transition process to e-government applications. (Çarıkçı, 2010: 102). The increasing trend towards digitalization has made it necessary to adjust the content of the transactions in the publics. With the emergence of digitalization, new e-transformation in public institutions brought along e-government or e-signature strategies 
Today, information services through e-government web sites in Turkey, integrated electronic services, such as payment processing services and institutions of access to short cuts are available. The e-government, which is said to be the public administration system of the information society, is considered as an indispensable application of public administrations, who are aware that they offer services to the information society or the postmodern society (Aydın, 2013: 263). In general, the egovernment provides mutual interaction between public administration and citizens through the internet. This interaction is aimed at reducing time consuming and unnecessary bureaucratic processes.

Public institutions are expected to serve equally to all citizens. The e-government used in public service delivery can be expressed as an online site that provides a single point of access to all public services. The aim of this application is to provide public services in an efficient and efficient way by using information and communication technologies to citizens, enterprises and public institutions (url1). Web Accessibility is important in e-government applications. Web Accessibility is the ability for all users (including people with disabilities and older people) to access, use and understand interfaces in e-government structure. At the core of accessibility there is information and guidance (Ertürk, Şimşek, Songür, Şengül 2014: 386-387). Therefore, public websites should be accessible and available to citizens from all walks of society. Public websites will be accessible to all users, and citizens or disabled users who are unable to go to the institution will benefit from the services provided and facilitate their lives.

Another concept of the study is the trademark. Trademark, as the word meaning Turkish Language Institution in the Dictionary of Economic Terms; a registered name, abbreviation, or sign, used to promote a good, service or service. Legally, the trademark is called trademark or alamet-i farika (url2). According to Article 4 of the Industrial Property Law No. 6769, words, figures, colors, letters, including person names, should be provided to distinguish the goods or services of an undertaking from the goods or services of other undertakings, provided that the subject matter of the protection provided to the trademark owner is clearly and precisely understood in the register. It can be defined as any type of markings, numbers, sounds and the format of goods or packages (url3).

Kotler and Armstrong (2004) trademark; the name, symbol, design (design), shape, color or various combinations of them are defined as the name, symbol (symbol), design, design and differentiation of the goods and services of one or a group of producers and / or sellers. Kapferer is a different definition in the context of trademark marketing; that trademarks have meanings far beyond the naming of goods and / or services of businesses; It is stated that trademarks are an important part of a strategy in which the differentiation of supply and the division of the market is aimed (Kapferer, 1992: 10). In short, it creates competitive added value by creating added value for the company.

Alıca (Alıca, 2008: 37) trademark in the legal context; One of the most important indicators of the knowledge-based economy is the increase of goods with symbolic or intellectual property. At this point, the integration of globalization and world economy has made the trademark important. In a globalized economy, it is a symbol that guarantees the quality or sought after standard that provides the identity of the products and services that distinguish the goods and services of an enterprise from the goods and services of thousands of companies around the world.

The World Intellectual Property Organization (WIPO-OMPI) is a trademark that is able to distinguish the trademark from a business, goods or services of a business from other businesses. Trademarks are protected by intellectual property rights. (url4). According to the American Marketing Association (url5); It is a name, concept, design, symbol, or a combination of all of which identifies the goods and / or services of a vendor or vendor group and distinguishes them from competitors. In the light of these definitions; to identify and differentiate the goods and / or services purchased by consumers and to differentiate them from the goods and / or services of other enterprises; to create an identity or image; By means of the values it adds to the product, such as providing communication, we can define it as a strategically important element in the focus of marketing activities.

Within the scope of the above explanations; two elements emerge. The first one is the evaluation of the trademark in the context of marketing and the other is legally defined. The trademark is used to achieve a specific marketing purpose. Trademark, The most important element that adds power and value to companies. It is stated that the trademark has more meaning than the name or symbolization of products and services in terms of business. The trademark is the communication between the consumer and the product by adding value and value to the trademark. For this reason, it is the key that allows consumers to choose among similar products or services on the market. 
The trademark has a feature that goes from the registration process to the value process. Kotler has defined the trademark as a name, term, sign, symbol or design, or a combination thereof, which enables the identification of the goods and services of a firm or a group of companies and distinguishing them from their goods and services. (Kotler, 1997: 789). In other words, the trademark; a name, term, sign, symbol, or design, or a combination of these, designed to separate a business or business group from its competitors to identify its goods and services.

Trademark is an immaterial right. Just like a house of people can be thought of as a car. For this reason, the trademark can be sold as rent (licensing) as it can be sold. The most important issue during trademark registration is the selection of the trademark and the determination of the goods or services to be covered by the trademark registration. The trademark must be differentiated in such a way that it can be distinguished from the trademarks that are not registered or used by others. After the trademark selection is made, the first job is to investigate whether the trademark is registered or not. After the trademark has been determined that it is not registered in the name of someone else, it is necessary to apply for trademark registration. In case the application is made without research about whether the trademark is registered in the name of someone else, the investment can be wasted if the trademark is registered in the name of someone else.

According to Turkish Patent Standards, 45 different class registrations are foreseen. There are sectors within each class. If the trademark is registered in which classes, the trademark is protected only in those areas of activity. Other areas cannot be claimed. According to the Turkish Patent and Trademark Authority (Turkish Patent) applications, trademark registration procedures are completed within an average of 6-7 months. After the application for trademark registration, the period of the research and investigation period by the Turkish Patent and Trademark Authority for absolute reasons lasts 2-3 months on average. If there is no obstacle related to the application in question, the trademark is announced in the Official Trademark Bulletin. The reasons for the rejection of the trademark application include the presence of the same or similar trademark and non-distinctive trademark.

The legal notice period is 2 months in the Trademark Bulletin. If there is no objection, the registration process is in progress. In case of objection, the applicant can give an opinion against this objection at this stage. The experts in the Department of Trademarks Department make the decision by evaluating the relevant objection and if any, the counter opinion. Against one of the parties, this decision makes another appeal to the Re-examination and Evaluation Board (BOT), which is the top authority of Turkish Patent within two months following the notification of the decision. The verdict of the BOT is final and at this stage it is possible to file a lawsuit against the final decision against the parties before the Ankara Intellectual Property Court for a period of 2 months from the date of notification of the decision. (Gümüş and Algül, 2018: 187-188). In case of no objection and within the legal period granted by Turkish Patent, wage deficiencies are completed. After the completion of all these transactions, within 1 month, the "TRADEMARK REGISTRATION CERTIFICATE" is received

According to the Industrial Property Law, the protection period can be extended for an unlimited period if the trademark protection period is renewed for 10 years only after 10 years from the date of application. For the extension of the protection period, the Turkish Patent and Trademark Authority should be renewed (6769 Sayılı Sınai Mülkiyet Kanunu, 2017: 20). In addition, it should be considered that the trademark must be used in the goods list in the goods list within five years from the date of registration and that the trademark can be canceled by the court upon request for the goods that are not used.

\section{Research}

In In this study, the contribution of globalization and digitalization to brand registration applications has been evaluated in integrating public services into digital environment. In this context, physical brand registration application and post-registration processes, online trademark registration and post-registration procedures, weaknesses and strengths of online transactions, online and physical brand registration application numbers per year and the issues related to the comparison of these numbers are examined.

In this study, a semi-structured interview which is one of the qualitative data collection methods as a method of application in e-government trademark registration procedures related to the 
integration of public services into digital environment has been realized. In practice, the Turkish Patent and Trademark Authority President Mustafa Kubilay GÜZEL was interviewed. Study; On January 1, 2008, it was determined that the Turkish Patent and Trademark Authority started to receive applications via the online system. In this respect, between January 1, 2008 and December 31, 2015 between the number of trademark application and the 10-year period specified by the process of making comparisons between the established criteria and interpreted by commentary and this interpretation was supported by a semi-structured interview.

The findings as a result of the research and examination and the findings obtained as a result of the interview are listed below.

Applications to Turkish Patent were made physically before 01.01.2008. The physical application was communicated to the institution directly or by mail / cargo by filling the forms determined by the institution appropriately by adding the bank receipt. After the receipt of the paper from the general paperwork unit, the documents consisting of the paper rolls are sent to the documents within 3-4 days after the screening. This application is registered in the trademark register 6 to 10 days after the completion of the screening process. However, on January 1, 2008, Turkish Patent and Trademark Authority started to take applications from online with the online system. Before the trademark registration application and other transactions, the trademark application has been activated with mobile signature and e-signature. The online system is a process that allows applicants, patent attorneys, and trademark agents to make all requests for industrial property rights through egovernment. It is ensured that transactions related to all requests related to trademarks, patent / utility model, Design and Integrated Circuit Topographies can be obtained online. The aim here is to fill in all the processes in a way that makes them more efficient and without causing any confusion.

Online system; instead of applying directly to the Turkish Patent by mail or by applying directly to the Turkish Patent, it allows access to the applications via e-government via the web portal. Trademark application or other transactions with the e-government who want to password Republic of Turkey ID number and password to the process by providing input to the portal is carried out. Before May 2018, the connection to the portal could be done by e-signature or mobile signature. Those who do not have an e-signature or mobile signature will be able to start the application process by logging in again with the system on the website. These persons will log into the online paper system on the website of the Turkish Patent and Trademark Agency. In this way, it is important to note that the application form must be delivered by hand or by mail to the documents department within 30 days. In other words, in order to complete your application, in addition to entering the system, it must be submitted to the Authority in the form. The application date for the applications with reservation will be the date of delivery of the form to the institution, not the date it was created.

It works on all browsers (Chrome, Firefox, Explorer) for trademark registration applications or other transactions via the online system. However, it is also possible to use Firefox, Chrome browsers There is a problem related with 32 bit-64 bit uyumsuzluğu in IE) in order to make the system more comfortable to use and to avoid possible configuration problems. In order for the required applications to be installed to install the necessary plugins for browsers, it will be healthy for web browsers to be closed (url6).

The images to be used in the application must be in RGB mode with $300 \mathrm{DPI}$ resolution and jpeg extension $5 \times 5 \mathrm{~cm}$ or $7 \times 7 \mathrm{~cm}$. Otherwise, the system gives an error and the message of these features is displayed on the screen. Necessary Applications works in all versions of Java, Acrobat Reader works in all versions (url7)

Thanks to the internet, which is able to convert the world into a market that can be reached by foot, the citizens can make their transactions more comfortable with the online application system. Although digitalization is seen as a process that causes people to get out of their homes less frequently, everything has been done on a keyboard by eliminating the problem of waiting to get more information than before. The transactions can be done in a short time without having physical contact with leaving the place, waiting or spending time. On the other hand, the online system, which is part of the digitalization, enables the development of business processes and the ability of the institutions to increase. 
All transactions related to the trademark registration application, which is the subject of our study, are the transactions carried out by the owner of the right for the purpose of registering the trademark with the special registry held by Turkish Patent and Trademark Authority. In online applications, trademark applications or other transactions are commonly performed digitally, since the government grants a significant advantage. Applications made through this system provide economic advantages to the applicants as well as time.

The Turkish Patent aims to use the technology in the meeting of citizens with the services through e-government application. Trademark registration application or other transactions with this technology by reducing the need for public employees and wasted time. With the on-line (online) system, the cost of mail and stationery processing is reduced. One of the most frequent transactions, the process of trademark registration applications, which lasted for an average of 10-15 days, was registered with the online system and it was recorded in the trademark registry in a short time such as 8 minutes. The process of scanning the application documents in physically registered trademark registration applications has also disappeared.

In the online system of the Turkish Patent, there are 5 main headings in the application process, post-application processes, customer transactions, other transactions and document display. The requested transactions are carried out with the help of these main headings. The document viewing process is an archive of the system. The Customer Transactions menu changes the name, address, contact, tax information of the applicant. In the post-application transactions menu, there are 33 items related to the trademark registration application or registration.

Due to the digital storage of documents, the online system also facilitates access to documents. The time elapsed for searching the documents in the archives and the time required for the arrival of these documents has disappeared. Because the requested documents are stored in the document viewing section of the online system, it enables access to the documents without any download restrictions. In addition, the cost of archiving and the easing of control are among the most important advantages of the system.

With the on-line (online) system, reliability, convenience and ease-of-use have been provided for the citizens to be more passive. The main objectives of the online system applications are to enable individuals to make their transactions in a shorter time, to reduce costs, to reduce bureaucracy by making transactions without going to institutions, to eliminate bureaucratic cumbersome, to keep up with the requirements of the era, to establish accountability and transparency. functions such as alleviate. In short, the main aim of the online system is to produce the highest quality service in return for minimum cost and labor.

In addition to the advantages of the online system, the disadvantage is that the money transfer transactions carried out in the electronic environment cannot create a sense of security (copying, stolen, sold, etc.) of the individuals due to the security and confidentiality issues and the digital money transfer of the individuals due to the lack of $100 \%$ security. He is frightened.

Table-1 Summary Table for Comparison of Physical and Online Transactions

\begin{tabular}{|l|l|l|}
\hline NAME OF OPERATION & PHYSICAL & ONLINE \\
\hline Time & Long & Short \\
\hline Cost & Increasing & Decreasing \\
\hline Labor & Increasing & Decreasing \\
\hline Bureaucracy & Increasing & Decreasing \\
\hline Processing Time & Long & Short \\
\hline Arschive Cost & There is & There is not \\
\hline Documentation & Long & Short \\
\hline
\end{tabular}


In order to support the findings of the study, a face-to-face meeting was held with the Head of Trademark at the Turkish Patent and Trademark Agency Mustafa Kubilay Güzel. Online applications and applications were put into service in 2008 and they have been expanding their scope since then and have taken their place among the indispensables. Considering the period in which it was put into service, TURKPATENT carried its transactions to the online platform and underlined that it was the first public institutions to accept applications with e-signature application. In addition, when compared with the Intellectual Property and Intellectual Property Offices abroad, TURKPATENT has emphasized that it has taken its place among the first offices that provide electronic application and electronic service. Although it is an assertive aspect of calling online operations as revolution, it has been said that it provides a historical transformation in the work and operations of both internal and external users. Mr. Güzel stated that online transactions provided the concept of predictability especially in terms of trademark registration processes besides operational facilities and advantages. The opening of the trademark database to the research has made it possible for a trademark to present information about the likelihood of a trademark in terms of its likelihood, thus allowing the applicant or proxies to identify similar trademarks and to manage their applications in a healthier way. He stated that there are two basic issues about the disadvantages of online transactions. The first of these is the existence of the limits of being able to load / download documents in the digital environment (limited to $50 \mathrm{MB}$ ) and the necessity to present the documents in the physical environment more easily and possible. It is stated that this situation constitutes a problem in terms of evidence which is not possible to be transferred to catalog or digital environment in such operations as objection.

Considering the problems in the following, it is possible to list the following:

a. Non-user-friendly interfaces,

b. Short-term and long-term unplanned outages

c. Instant online application errors

d. Failure to solve errors encountered due to limited human resources

In addition, the management of problems in an office where electronic application systems are used so heavily, and in the sense of the lawfulness of the solutions found, may lead to a problem in the absence of an "Regulation on Online Implementation". It can be clarified what will be done with a Regulation that will be made on issues such as the fact that the transaction cannot be carried out for a period of time due to the online application of the Institution.

Considering that online transactions are done on the internet, the issue of "Cyber Attack" has been highlighted from time to time. Mr. Guzel stated that such problems as the Turkish Patent and Trademark Authority have not been encountered so far, and that access studies of 27001 standards have been carried out actively in order to prevent such initiatives and provide information security.

The information in the table below is taken from the official website of the Turkish Patent and Trademark Authority and is generally evaluated without considering the class number or category (NICE classification) of the trademark applications. 
Table-2: Online and Physical Trademark Registration Application by Years Investigation of numbers

\begin{tabular}{|l|l|l|l|l|l|}
\hline YEAR & PHYSICAL & ONLINE & TOTAL & $\begin{array}{l}\text { ONLINE } \\
\text { PERCENT }\end{array}$ & $\begin{array}{l}\text { PHYSICAL } \\
\text { PERCENT }\end{array}$ \\
\hline $\mathbf{2 0 1 8}$ & 15038 & 104970 & $\mathbf{1 2 0 0 0 8}$ & $\% 87$ & $\% 13$ \\
\hline $\mathbf{2 0 1 7}$ & 24433 & 96675 & $\mathbf{1 2 1 1 0 8}$ & $\% 80$ & $\% 20$ \\
\hline $\mathbf{2 0 1 6}$ & 22722 & 84454 & $\mathbf{1 0 7 1 7 6}$ & $\% 79$ & $\% 21$ \\
\hline $\mathbf{2 0 1 5}$ & 29113 & 81566 & $\mathbf{1 1 0 6 7 9}$ & $\% 74$ & $\% 26$ \\
\hline $\mathbf{2 0 1 4}$ & 29975 & 81569 & $\mathbf{1 1 1 5 4 4}$ & $\% 73$ & $\% 27$ \\
\hline $\mathbf{2 0 1 3}$ & 32251 & 76357 & $\mathbf{1 0 8 6 0 8}$ & $\% 70$ & $\% 30$ \\
\hline $\mathbf{2 0 1 2}$ & 31732 & 79411 & $\mathbf{1 1 1 1 4 3}$ & $\% 71$ & $\% 29$ \\
\hline $\mathbf{2 0 1 1}$ & 33466 & 84257 & $\mathbf{1 1 7 7 2 3}$ & $\% 72$ & $\% 28$ \\
\hline $\mathbf{2 0 1 0}$ & 32595 & 52533 & $\mathbf{8 5 1 2 8}$ & $\% 62$ & $\% 38$ \\
\hline $\mathbf{2 0 0 9}$ & 30719 & 40885 & $\mathbf{7 1 6 0 4}$ & $\% 57$ & $\% 43$ \\
\hline $\mathbf{2 0 0 8}$ & 46767 & 28224 & $\mathbf{7 4 9 9 1}$ & $\% 38$ & $\% 62$ \\
\hline
\end{tabular}

Chart 1. Distribution of Online Trademark Numbers by Years

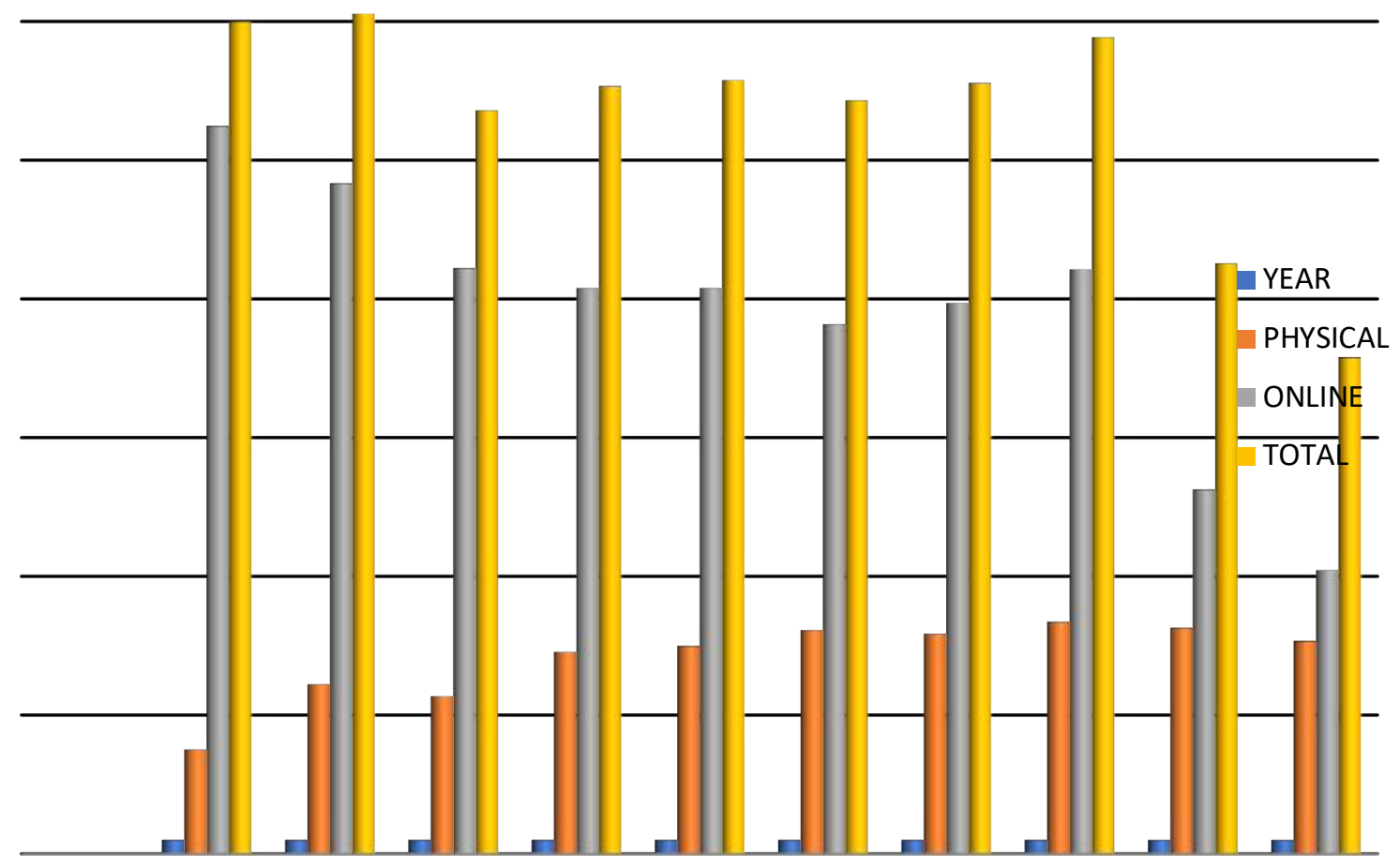

As can be seen from the table above, the online applications of the Turkish Patent Institute to the internet have increased significantly from 2008 to 2011 , while a decrease of $2 \%$ has been detected between 2012 and 2013, and after 2013, until the increase was observed. In 2008, only 38\% of all applications included online applications, and by 2018 , this figure increased to $87 \%$. It was found 
that there was an almost 2.7 fold increase in online applications over a period of 10 years. Taking into account the decrease in online applications in 2011 and 2012, the percentage of online applications in 2018 increased from $70 \%$ to $87 \%$. It is believed that the biggest share in this increase is due to the noticeable low-price difference from the fees paid in accordance with the physical applications and the fees in the trademark registration application and other transactions.

Head of Trademark Department at the Turkish Patent and Trademark Authority Mustafa Kubilay Güzel stated that, two main reasons, the increase in the predisposition to the Internet environment and the advantages of the electronic application system is to become more widereaching experiences, in addition to the e-signature instead of e-signature on a micro scale, the encouragement of the use of these systems in corporate information and the promotion of electronic application by differentiation in the charge notification.

However, the application or other process in all the borders of Turkey, any mail of citizens considering that even made the international area / cargo operations to the operation from his seat of requirements is a reference number by making a practical way. In addition, the fact that the applications that are delivered to the cargo / mail to reach the institution is also a minor factor. In summary, by utilizing the technology of public services, the electronicization of these services by the internet can be expressed as the increase of demands by citizens for lower costs and technical convenience.

\section{Conclusion}

In recent years, Globalization and digitalization (digital technologies), which are two of the most frequently felt phenomena have led to developments or changes in our behavior patterns and economy as in culture. Thanks to these developments, globalization has become an increasingly small living space for societies. As a result of globalization as a natural consequence of the developments in communication, it has initiated a new process that involves the digitalization and digitization of analog material or information flows and the use of new business strategies. Technological developments have been a catalyst for the success of these efforts in a short time.

These changes created by digitalization in many disciplines are clearly seen to play an important role in the development of information technologies. The increasing use of the Internet, as a technological extension of people no longer only with muscle power; With the power of mind has become all the operations. This digital transformation has been a close-up of everything by dramatically changing the access and sharing of information. With the digitalization, the methods of companies, individuals or institutions are no longer local.

The rapid developments in information and communication technologies, which are now accelerated by globalization, vary considerably according to public institutions, changing conditions and needs of today. It has also caused changes in all parameters of the local and globalization processes of the enterprises. Almost everything can be measured in the era of digital transformation, and every important decision about institutions can be supported by data and analytical implementation (Ohlhorst, 2013: 32). Thus, with globalization, transactions have to be made quickly and reliably from a single portal.

With the impact of globalization, the trademark has moved to a different dimension. This situation was realized both in the context of marketing and in the legal context. The trademark which has become a necessity, has made its importance felt with the advantages and benefits of its use and the advantages it brings to the parties. Trademarks a product that performs functions such as distinguishing products from their competitors and emphasizing their quality, created a value independently from the products that they introduced, and were among the material assets of the companies. In this respect, the importance of the trademark in legal sense is only possible with the registration of the trademark. Because the trademark is an informal right.

This is presented in Turkey work done on the platform for online and digital media with egovernment through the post-processing trademark applications and the application and dissemination of these practices, development will make contributions to the country, is considered our country has can be led to the development of secure private infrastructure. Because the documents to be signed 
mutually and the copies in the paper environment will not need to be physically carried between the parties. Information and documents can be transported online in electronic form on the basis of users' permission, thus saving paper. Since the transportation of these information and documents between the parties will be made in electronic environment, time and service saving will be provided.

The proliferation of e-government services will undoubtedly reduce resource and time wastage, and increase productivity will lead to the aim of achieving economic recovery and a welfarelevel society. Due to the security of these transactions made over the internet, it can be observed more frequently that the application on the internet after trademark application and application is made. Thus, it will affect the increase of safe online applications.

In other words, it will play an important role in social change and transformation by means of online applications and it will have positive results in terms of economic, technical, legal and social developments and will make a great contribution to its spread.

The effect of the digitization process on working life or the digitization of working life has played an important role in the work of a public institution, Turkish Patent and Trademark Authority. Although Turkish Patent has a number of technical and social infrastructure deficiencies, these shortcomings are at the minor level and do not hinder the processing of citizens or proxies. The solution of minor problems is not a problem that requires long term but it is envisaged that it can be solved in a shorter time by a planned study.

\section{References}

[1] Akın, B. (2001). Yeni Ekonomi Strateji Rekabet ve Teknoloji Yönetimi. Konya:Çizgi Bookstore

[2] Alıca, T. (2008). Markanın Hukuki ve Cezai Koruması. İstanbul: İstanbul Bar Association Publishing, 37.

[3] Aydın, A H. (2013). Kamu Yönetimine Giriş. Ankara: Seçkin Publishing.

[4] Bauman, Z.(2017). Kürselleşme, İstnabul: Ayrıntı Publishing.

[5] Buffat, A. (2015). "Street-Level Bureaucracyand E-Government", Public Management Review, 17(1), s. 149-161.

[6] Cordella, A., Tempini, N. (2015). "E-GovernmentandOrganizationaChange: ReappraisingThe Role of ICT andBureaucracy in Public Service Delivery", Government Information Quarterly, s. 279-286.

[7] Çarıkçı, O. (2010). "Türkiye'de Edevlet Uygulamaları Üzerine Bir Araştırma”, Süleyman Demirel

University Social Sciences Institute Publishing (12), s. 95-122.

[8] Ertürk, K. L., Şimşek, A. A., Songür, D. G., \& Şengül, G. (2014). Disabilityawareness in Turkeyand an Assessmentaboutaccessibility of Web Pages related to Justice by disabledpeople.

[Türkiye'de Engelli Farkindaliłi ve Engelli Bireylerin Adalete Web Erişilebilirlikleri Üzerine Bir Değerlendirme] Bilgi Dünyası, 15(2), 375-395.

[9] Gümüş, S. \& Algül A., (2018). Pazarlama İletişimi Bağlamında Markanın Tescili Sonrası Konumu: Eti, Ülker ve TorkuÖrnekleri, İstanbul: İstanbul Aydın University New Media Electronical Magazine.

[10] Giddens, A. (2004). Modernliğin Sonuçları (Trans: Ersim Kuşdil), İstanbul: Ayrıntı Publishing.

[11] Hepkon, Z. (2011). İletişim Ve Teknoloji. İstanbul: Kırmızı Kedi Publishing.

[12] Mcluhan, M. (1962). The Gutenberg Galaxy. Toronto: University of Toronto.

[13] Kotler, P. (1997). Marketing Management., New Jersey: PrenticeHall International Inc.

[14] Ohlhorst, F. (2013). Big data analytics: turning big data intobig Money. New Jersey.

[15] Özcivelek, R. (2003). Dünyada Ve Türkiye'de Elektronik Devlet Tartışmaları: Kavram Üzerine Bir Sorgulama. Ankara: Tübitak-Bilten. 
Communication and Technology Congress - CTC 2019 (April 2019 - Turkey, Istanbul)

[16] Sönmez, M. (2016). "Kamuda Teknoloji Kullanımı, Avrupalılaşma, Etkinlik ve Verimlilik Açısından

Tek Numara (112) Acil Çağrı Merkezleri ve E-Çağrı(E-Call) Uygulamaları", Turkish Government

Magazin, 149-182.

[17] T.C. Ulaştırma, Denizcilik ve Haberleşme Bakanlığı, e-Devlet Hizmetleri Dairesi Başkanlığı, 2016-2019 Ulusal e-Devlet Stratejisi ve Eylem Planı (http://www.edevlet.gov.tr/wpcontent/uploads/2016/07/2016-2019Ulusal-e-Devlet-Stratejisi-ve-Eylem-Plani.pdf, 01.09.2017).

[18] Yankın, F. B. (2019). Dijital Dönüşüm Sürecinde Çalışma Yaşamı, Edirne: Trakya University Faculty of Economics and Administrative Sciences e-Magazine 7 (2), 1-38,

[19] Yengin, D. (2012). "Sosyal İletişim Aracı Olarak Akıllı Telefonların Oluşturduğu Uygulama Toplumu Olgusu: WhatsApp Uygulaması”, (Editörler), Tolga Kara ve Ebru Özgen, Sosyal Medya Akademi, İstanbul: Beta.

[20] url1, https://www.turkiye.gov.tr/bilgilendirme?konu=siteHakkinda Erişim tarihi:15.03.2019 İktisat Terimleri Sözlüğü”, Türk Dil Kurumu Resmî Web Sitesi,

[21] url2, http://www.tdkterim.gov.tr/?kelime=marka\&kategori=terim\&hng=md, Erişim Tarihi: 28.02. 2019

[22] url3, http://www.mevzuat.gov.tr/MevzuatMetin/1.5.6769.pdf Erişim tarihi: 10.03.2019 Marketing Power, American Marketing Association,

[23] url4, http://www.marketingpower.com/layouts/Dictionary.aspx?dLetter=B (Erişim tarihi: 20.022019.)

[24] url5, https://www.turkpatent.gov.tr/TURKPATENT/onlinehelp/Erişim tarihi: 10.03.2019 